\title{
Sustainable Ecotourism Development Analysis in Bandar Lampung City Tourism Object
}

\author{
Darmawan Purba \\ government science \\ Lampung University \\ Lampung, Indonesia \\ darmawan.purba@fisip.unila.ac.id
}

\author{
Ismono Hadi \\ government science \\ Lampung University \\ Lampung, Indonesia \\ ismono.hadi@ fisip.unila.ac.id
}

\author{
Bendi Juantara \\ government science \\ Lampung University \\ Lampung, Indonesia \\ bendi.juantara@fisip.unila.ac.id
}

\begin{abstract}
The city of Bandar Lampung is currently facing serious problems related to environmental degradation. Various efforts have been made by Lampung Provincial Government and Bandar Lampung City Government to carry out the arrangement. However, there are still many problems and obstacles. To achieve the objectives of this study, the researcher uses a descriptive qualitative approach. The results of the study show that there are three tourism objects with natural attractions that focus on environmental sustainability aspects, however, at the service aspect, only 2 (two) tourism objects are managed professionally, namely the Sakura Hills and Puncak Mas attractions, while the Binoculars Attractions in Bukit Sindy City did not yet have sufficient managerial system due to minimal services and access to facilities. On the other hand, the local culture aspect has not become a priority to be used as a special theme for the tourism object. Even so, in the aspect of community involvement, the 3 (three) tourism objects have opened access to the surrounding community to participate in managing and sharing economic benefits Moreover, tourism actors have given serious attention to developing innovation and creativitybased tourism.
\end{abstract}

Keywords-Sustainable Ecotourism Development, Bukit Tourism, Bandar Lampung City.

\section{INTRODUCTION}

Tourism is one of the new types of industry that can generate rapid economic growth in terms of providing employment, living standards, and stimulating other productivity sectors. In addition to generating foreign exchange and expanding employment opportunities, the tourism sector aims to preserve nature and develop local culture [1]. Tourist attractions are divided into natural tourist attractions, artificial tourist attractions, and cultural attractions Meanwhile, according to Suwantoro [2] tourist attraction consists of the exploitation of natural tourist attractions, cultural tourist attractions, and special interest tourist attractions.
Since the enactment of regional autonomy, the development of tourism in Lampung Province has increased quite significantly. Strategic potential tourism attractions such as mountains, beaches, protected forests, hills, and nature reserves have encouraged tourist visits to increase every year. Lampung's strategic location has also made the area a potential place to be developed as a sustainable tourism destination. Since 2017, Bandar Lampung City is an area with the highest visit rate, it is natural because the development of tourist attractions in Bandar Lampung City has been regulated in regional regulations. Based on Article 56 of the Regional Regulation of Bandar Lampung City No 10/2011 concerning Tourism Areas, provides directions for Bandar Lampung City tourism area development into 5 (five) zones, one of which is natural tourism zone. The natural tourism zone of Bandar Lampung City is located in the coastal area of Lampung Bay and hilly areas. The beauty of the 2 (two) natural zones has indirectly become an icon or landmark of Bandar Lampung City.

Unfortunately, Bandar Lampung City is currently facing serious problems related to environmental degradation. The hill area as a water storage area and the main hydrological regulator system in Bandar Lampung City has suffered severe damage. One of the reasons is the massive conversion of hills into tourist attractions and the failure of environmental-based hill tourism management. Whereas, the fact that tourism development needs to pay attention to regional conditions as well as physical and non-physical factors, to avoid excessive environmental damage. Therefore, the development in the tourism sector should consider the principles of environmentally sound development and local community development. The development of environmentally sound tourism is a tourism development that gives a high contribution to the local community's economy. In other words, the 
development should be able to increase people's income while maintaining environmental sustainability and cultural values.

TABLE I. PROBLEMS IDENTIFICATION OF HILL TOURISM OBJECTS IN BANDAR LAMPUNG CITY

\begin{tabular}{|l|l|}
\hline \multicolumn{1}{|c|}{ Hill Name } & \multicolumn{1}{|c|}{ Activity Cause Problem } \\
\hline Bukit Sindy & $\begin{array}{l}\text { 1. Continuous grinding of hills. During the rainy season, it is feared that the material from the scoured hills } \\
\text { will be carried away to residents' settlements } \\
\text { 2. Logging of trees to replace infiltration tree land with permanent buildings or wooden buildings, where } \\
\text { it is feared that rainwater will not be absorbed into the ground, thus potentially causing flooding. } \\
\text { 3. The access road to the hill has been asphalted, this has the potential to cause landslides } \\
\text { 4. There is a social conflict with the surrounding community who are exposed to the landslide hazard zone }\end{array}$ \\
\hline Bukit Sakura & $\begin{array}{l}\text { Water infiltration is lost due to scouring the hill to be used as a tourist attraction } \\
\text { Puncak Mas } \\
\text { places, photo spots, places of worship, restrooms, etc. It is feared that there will be potential flooding } \\
\text { and landslides. } \\
\text { 2. Tourism objects in ideal areas should be able to increase the regional budget because of the taxes that } \\
\text { must be paid to the regions. However, what happened is, on the contrary, Bandar Lampung City } \\
\text { Government released data on tourist attractions that were increased in numbers. One of which was } \\
\text { Puncak Mas and Bukit Mas on Jalan Haji Hamin, Sukadanaham, Tanjung Karang Barat but both places } \\
\text { had evaded taxes since 2017. The taxes consist of parking taxes, restaurant taxes, city taxes, and } \\
\text { advertisement taxes which are estimated to have reached millions of hundreds of rupiah. The city } \\
\text { government claimed to have sent 3 (three) letters to the Puncak Mas manager but there was no response. }\end{array}$ \\
\hline
\end{tabular}

The damage effect to the hills of Bandar Lampung City has had a wide impact on the city's ecosystem, for instance triggering floods and landslides. Various efforts have been made by Lampung Province Government and Bandar Lampung City Government to make arrangements. This can be seen from the Regional Regulation No. 6/2012 concerning the Master Plan for Regional Tourism Development of Lampung Province, Lampung Province Regional Regulation No 1/2010 concerning Regional Spatial Planning (RTRW) of Lampung Province from 2009 to 2029, Bandar Lampung City Regulation No. 10/2011 concerning Regional Spatial Planning (RTRW) of Bandar

TABLE II. FLOOD LOCATION DATA IN BANDAR LAMPUNG CITY 2010-2019
Lampung City 2011-2030, and Bandar Lampung City Regulation No. 03/2017 concerning Tourism. However, the flood disaster spreads to the downtown area.

Based on disaster location data from 2010 to 2019 from the Regional Disaster Management Agency (BPBD) of Bandar Lampung City, it is known that from 2010 to 2019 flood cases in Bandar Lampung City continued to repeat every year. The following is a list of flood cases in Bandar Lampung City from 2010 to 2019:

\begin{tabular}{|c|l|}
\hline Year & \multicolumn{1}{|c|}{ Flood Point Location } \\
\hline 2010 & Kaliawi, Rajabasa, Jagabaya Satu, Beringin Raya, WayHalim \\
\hline 2011 & $\begin{array}{l}\text { Kuripan, Palapa, Kelapa Tiga, Pakiskawat, Sumur Putri, Gulak-galik, Kupang Teba, Sumurbatu, Garuntang, } \\
\text { Kangkung, Bumi Waras, Sukaraja, Way Kandis, Sepang } \\
\text { Jaya, Kampung Baru, Sukadanaham, Keteguhan, Langkapura, Sukamaju, Sukabumi, Sukarame, Kemiling }\end{array}$ \\
\hline 2012 & Ridwan Rais, Garuntang, Way Lunik, Penengahan,Flamboyan, Tanjung Gading \\
\hline 2013 & $\begin{array}{l}\text { Keteguhan, Olok Gading, Bakung,Gunung Agung, Karang Anyar, Sukaraja, Gunung Mas, Bumi Raya, Rajabasa Raya, } \\
\text { Way Lunik, Kerawang, Ketapang, Gunung Sulah, Jagabaya,Way Halim, Sukabumi, Bumi Waras, Kali Balau Kencana, } \\
\text { Way Dadi, Korpri Jaya, Tanjung Raya, Kupangt Teba, Sukadanaham, Kedaton, Sidodadi, Purwata, Keteguhan }\end{array}$ \\
\hline 2014 & $\begin{array}{l}\text { Kalibalau Kencana, Waylaga, Campang Jaya, Enggal, Way } \\
\text { Lunik, Sukaraja, Rajabasa, Nyunyai, Keteguhan, TanjungGading, Baypas, Jagabaya 3,Way Gubak }\end{array}$ \\
\hline 2015 & $\begin{array}{l}\text { Kelurahan Tupan Teba, Pasir Gintung. Geruntang, Kali Balok, Jalan Gajah Mada, Jalan Tamim, Olok Gading, Jaga } \\
\text { Baya, Kelpa 3, Kedton, IAIN Cut Mutia, RSUAM, TM } \\
\text { Pahlawan, Sebrng Bukopin, Pasar Kangkung, Kaliawi, JalanUrip Sumoharjo, Kelurhan Bangkung, Keteguhan }\end{array}$ \\
\hline 2016 & $\begin{array}{l}\text { Way Lunik, Panjang, Kalibalok Kencana, Kedamaian, Kaliawi, Tanjung Karang Pusat, Jalan Ryacdu, Gang Manggis, } \\
\text { Gang Jambu, Way Balau, Jagabaya II, sekitaran } \\
\text { Antasari Jl.H. Syarif }\end{array}$ \\
\hline 2017 & $\begin{array}{l}\text { Jalan Diponegoro Gang Nngka, Gunungmas, Teluk BetungUtara, Pasir Gintung, Tanjung Karang Pusat, Gedong } \\
\text { Air Dinas Sosial Bandar Lampung }\end{array}$ \\
\hline Sidomulyo, Tarahan, Rangai Tritunggal \\
\hline
\end{tabular}




\begin{tabular}{|l|l|}
2019 & Jalan ZA Pagar Alam, Jaan Pramuka, Rajabasa, Jalan HI. Sabari, Kelurahan Bumi Kedamaian, Talng, Teluk Betung \\
& Selatan, Ruas Jalan RA Kartini, Jembatan Sungai, Gang Citra, kampung Karawang Rajabasa, Garuntang, Jalan Abas \\
& Anang, Kelurahan Koala, Panjang Gang Nunyai, Rajabasa, jalan Ikan Baung, Gang Wakaf, Kupang Teba, Jalan HI. \\
& Sabari RT 14, lingkungan 2, Bumi Kedamaian, Perumahan Blora Persada, Kemiling, Jalan Urip Sumoharjo, \\
& Perempatan Lampu Merah Baypass, Serengsem, Panjang (depan PT Hanjung), Puskesmas Permata Sukarame, \\
& Belakang UIN, Sepang Jaya, Jalan H Komarudin Rajabasa, dan Jalan RA. Kartini (depan Hotel Horizon)
\end{tabular}

Based on the above data, this research has a general goal, namely to increase the understanding of the government and the private sector in developing tourism objects with a Sustainable Ecotourism Development approach. While the specific objectives of this research are: 1). To identify the use and management of environmentally sustainable tourism resources; 2). To find out the efforts of tourism development in preventing and overcoming the impacts of tourist activities; 3 ). To measure the effectiveness and efficiency of the Sustainable Ecotourism Development approach on hill tourism objects in Bandar Lampung City.

\section{RESEARCH METHODS}

The research method used in this research is descriptive. In this research, the descriptive method is used to find out and describe how to explore the problems of Bandar Lampung City related to environmental degradation. The hill area as a water storage area and the main hydrological regulator system in Bandar Lampung City has suffered severe damage, some of the hills have been converted into tourist attraction areas. This problem has a wide impact on the city's ecosystem, for instance, triggering floods and landslides. Various efforts have been made by Lampung Province Government and Bandar Lampung City Government to make arrangements, this can be seen from the Regional Regulation No. 6/2012 concerning the Master Plan for Regional Tourism Development of Lampung Province, Lampung Province Regional Regulation No. 1/2010 concerning Regional Spatial Planning (RTRW) of Lampung Province from 2009 to 2029, Bandar Lampung City Regulation No. 10/2011 concerning Regional Spatial Planning (RTRW) of Bandar Lampung City 20112030, and Bandar Lampung City Regulation No. 3/2017 concerning Tourism. However, there are still many problems and obstacles, including regulations that are investment-oriented, strong political relations between the government and the private sector for hill management, as well as the weak supervision by civil society on the hill object.

Based on the above data, this research has a general goal, namely to increase the understanding of the government and the private sector in developing tourism objects with a Sustainable Ecotourism Development approach. While the specific objectives of this research are: 1) To identify the use and management of environmentally sustainable tourism resources, 2) To find out the efforts of tourism development in preventing and overcoming the impacts of tourist activities, 3). To measure the effectiveness and efficiency of the Sustainable Ecotourism Development approach on hill tourism objects in Bandar Lampung City.

The method of data collection is namely by conducting field observations, unstructured interviews, documentation, and literature review. The results of observations that already obtained, starting from data collection, are 1) Identification of the usage and management of environmentally friendly tourism resources, 2). Identification of tourism development efforts in preventing and overcoming the impacts of tourist activities, 3). Measurement of the effectiveness and efficiency of the Sustainable Ecotourism Development approach on hill tourism objects in Bandar Lampung City.

\section{RESULTS AND DISCUSSION}

\section{A. Portrait of Bandar Lampung Hill Tourism Management}

Today, the government of the Republic of Indonesia is active in launching various national development planning activities in all aspects. Both in terms of human resource development (non-physical) and development from the physical aspect [3]. Since the fall of the Suharto era and the rise of reform, the spirit of hope for national development towards an independent and highly competitive nation has been embedded in the Long Term Development Plan (RPJP) 2005-2025 until it is made explicit in the Vision and Mission of the President and Vice President RI. To achieve this, all components need to unite to support all programs of national development activities.

One aspect of national development is tourism development. This object is important because it can encourage an increase in the rate of economic equality in Indonesia. Tourism contains aspects of foreign exchange earnings, equitable distribution of people's economic income, expanding employment opportunities, and alleviating poverty. One way to alleviate people's poverty is to provide opportunities for the poor to participate in economic activities such as the tourism business [4].

The impact of tourism development can be seen at the lowest level, after the Regional Government Law is enacted, the regions have the autonomy and authority to develop including encouraging regional development that is oriented towards increasing 
community welfare and utilizing the potential and capacity of each region. This tourism development is based on the tourism development master plan which consists of the national tourism development master plan (RIPPNAS), the provincial tourism development master plan (Provincial RIPPDA), and the regency/city tourism development master plan (Regency/City RIPPDA). Meanwhile, destinations at the regional level are regulated through a master plan for regional development, and at the tourist attraction level, it is regulated through a regional site plan and technical design.

However, tourism is not only from the economic aspect and people's welfare, but also important to look at other issues such as social context, and cultural dynamics, as well as supporting environmental conditions. This is as stipulated in Law Number 13 the Year 2011 concerning Sustainable Development Goals (SDG's) in Indonesia 2045. Tourism as one of the development activities is strived to be in line with the concepts and principles of sustainable development, where the utilization of the potential existing natural resources is not exploitative or the emphasis is only on profit issues. But it is also necessary to consider a comprehensive and integrated approach (policy). The sustainable combination allows for the collaboration of interesting natural value works to be marketed also driven by unique local cultural works and excellent service performance. Integrated management with a focus on sustainable environmental balance allows tourism potential to be carried out properly by taking into account the ability to manage eco-efficiency to achieve eco-effectiveness.

Tourism by utilizing hills or mountains as a destination is not new in Indonesia. If properly managed, a tourist attraction that utilizes hills or mountains is a way out to preserve the nature and culture of the community from the mere exploitation of nature. In this context, Bandar Lampung City has high potential in hill management. Based on the results of a field survey, Bandar Lampung City is topographically a hilly area with a total of 33 hills, including: Mount Kunyit, Mount Mastur, Mount Bakung, Mount Sulah, Mount Celigi, Mount Perahu, Mount Cerepung, Mount Sari, Mount Palu, Mount Depok, Mount Cats, Mount Banten, Mount Sukajawa, Bukit Serob, Jaha and Slopes, Buki Asam, Pidada Hill, Balau Hill, Hatta Hill Cluster, Cepagoh Hill, Kaliawi Hill, Palapa Hill I, Palapa Hill II, Gintung Sand Dunes, Mount Betung Foot Hill, Sukadanaham Hill, Susunan Baru Hill, Sukamenanti Hill, Klutum Hill, Randu Hill, Langar Hill and Camang Hill. However, of the hills, more than $80 \%$ have changed land use whether as a mining area, residential and commercial residential areas, hotel and restaurant areas, or natural tourist attractions.
In this context, this study tries to identify the extent to which the pattern of utilization and management of hill tourism resources in the Bandar Lampung City is environmentally friendly and to measure the effectiveness and efficiency of the Sustainable Ecotourism Development approach on hill tourism objects in Bandar Lampung City:

\section{a) Attractions Bukit Sakura Bandar Lampung}

Sakura Hill is one of the tourist attractions in Lampung that use a distinctive theme, namely the situation of the cherry/sakura in Japanese country. Various ornaments such as cherry trees, windmills, and traditional Japanese houses adorn various corners of the tourist attraction. The sakura hill area is in the Sukadanaham hills zone. This area is mostly hill contours with an altitude of 500 to 800 meters above sea level. In the management of the tourist attraction, the design of the location is built following the contours of the land so that it does not change the initial condition of the hill. This can be seen from the concept of the Sakura Hill land which is formed in stages downwards. This concept indirectly protects the hill above it so that landslides do not occur. This is also integrated with the maintenance of the tree's life quality spread in many points of these tourist locations, no wonder the atmosphere at the Sakura Hill tourist attraction is all green, fresh, and in a refreshing and comfortable state.

The location of Sakura Hill is in the suburbs of Bandar Lampung, as precisely on Jalan Melati Raya Langkapura, Bandar Lampung City. This location is remote and quite difficult to access. And because the road is narrow, tourists need to be careful to reach this tourist attraction area. In terms of security, this tourist attraction is far from crowds and there are minimal security signs that allow the practice of open crimes. Therefore, it is better to visit Sakura Hill during the day.

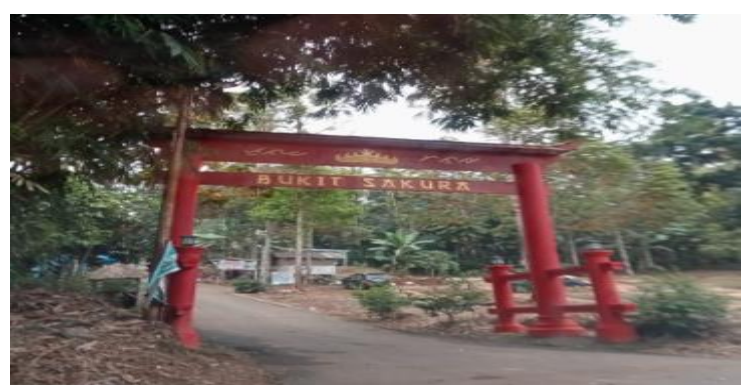

Fig. 1. Sakura Hill Tourist Attraction Gate

The Sakura hill tourist attraction is equipped with several facilities and quite complete rides to use. This can be seen from the availability of a wide and safe vehicle parking service, maximum customer service, unique restaurants and gazebos, karaoke, places of worship, and bathrooms. Tourists can also shop for 
Japanese souvenirs at the Sakura Hill Boutique and Minimarket. All the ride's objects and facilities are made in an orderly and neat manner. In addition, based on the observations, it shows that since entering the gate of tourist attractions and then visiting all rides, they appear to be in a clean condition and free from dirt, garbage, waste, disease, and pollution. Moreover, the serving of food and beverage is clean and healthy, whereas the staffs are also clean and tidy.

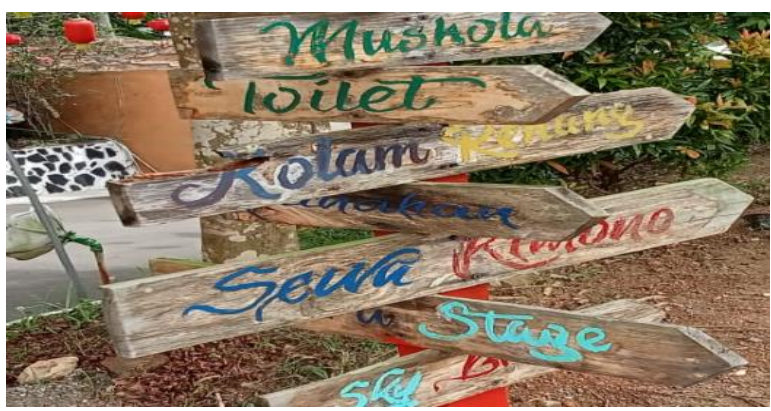

Fig. 2. Facilities At Sakura Hill Attraction

In the context of choosing tourist attractions theme, bringing up Japanese culture is an attractive choice for tourists. However, this does not mean reducing the space for local culture but more as part of the exchange and introduction of foreign cultures into the country. However, this Japanese-style theme is not completely adopted, such as the absence of museums about Japanese history and Japanese language classes for tourists who want to learn the Japanese language and culture firsthand.

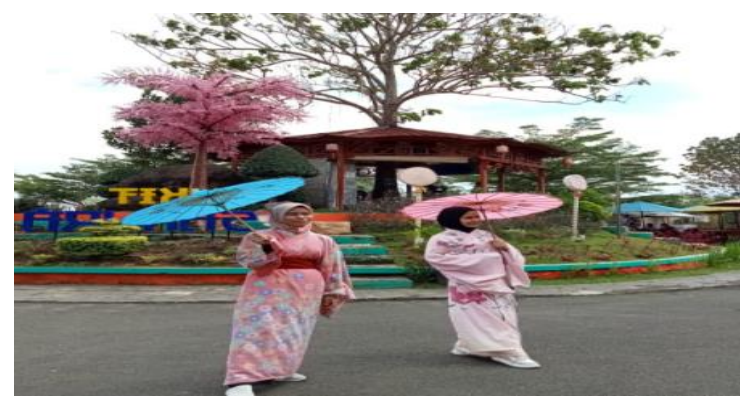

Fig. 3. Japanese Costume Rides Of Tourist

In another context, when referring to the environmental perspective that exists in Japan, tourism modeling with the Japanese concept is very interesting to be applied to hill tourism in Bandar Lampung city. This is because Japan has techniques and technology as well as special studies in the effort to keep the position of the environment unchanged even though it is empowered. Thus, the habits and environmental ethics of Japanese society towards environmental sustainability can also be used as examples, such as discipline in managing waste in public spaces, including tourist sites.

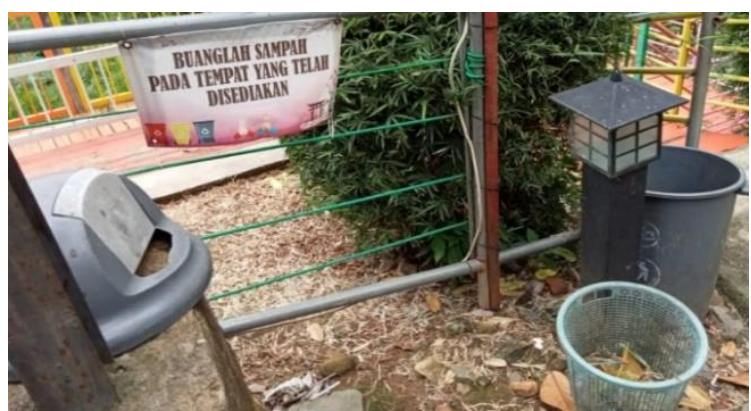

Fig. 4. Trash Can Facilities At Number Of Points

In terms of tourism management, the involvement of the local community in accepting the tourism economic impact can be seen in the establishment of food and souvenir stands in the area around the tourist attraction. Besides, the surrounding community is also allowed to be employees at the Sakura hill tourist attraction, for example as cleaners, parking attendants, and restaurant waiters. This means that tourism management is not only profitable or presents benefits for certain parties but also beneficial for the surrounding community.



Fig. 5. MSMEs Communities Around Tourism Objects

Based on the description above and the potential management of the Sakura Hill tourist, the opportunity for the sustainability of this tourist attraction in the future as a model tourist attraction for other tours is quite promising, apart from the unique tourist landmark, since it raises the theme of Japanese culture. It is also supported by the managerial system based on environmental sustainability though it needs more educative future development and sustainability.

\section{b) Attractions Puncak Mas Tourism Object in Bandar Lampung}

Puncak Mas tourist attraction is a tourist attraction similar to Sakura Hill tourist attraction. The location of this tourist attraction is on J1. PB. Marga, Sukadana Ham, Kec. Tanjung Karang Barat, Bandar Lampung City. Puncak Mas tourist attraction is located at the Sukadanaham hill points. This tourist attraction is quite accessible from Bandar Lampung City, but tourists need to be careful because the access road is uphill and there are minimal signs and street lighting. 


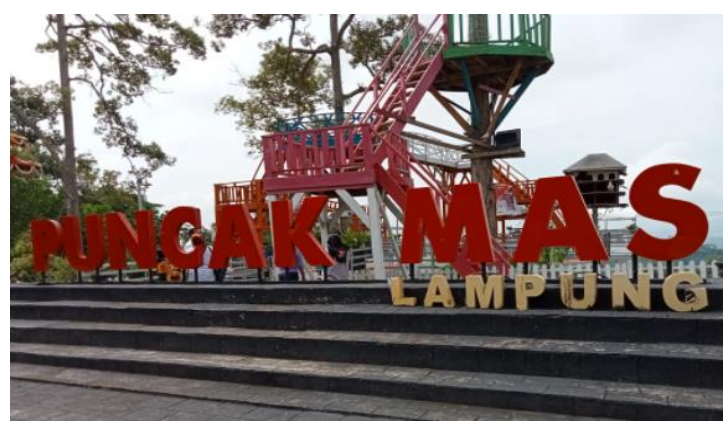

Fig. 6. Puncak Mas Area

\section{CONCLUSION}

This tourist attraction presents a variety of interesting, organized, and neatly arranged rides such as the Beautiful Garden in the Heights, which is a large, well-arranged park with the dominance of green grass, trekking areas, and gazebos available at several points. This elevated garden area features a beautiful golden sunset view and urban activities views during the day to the twinkling city lights at night. In addition, there are park rides at an altitude, visitors will also be presented with some interesting selfie spots such as hanging bicycle rides, also known as zip bikes, karaoke, and treehouse rides.
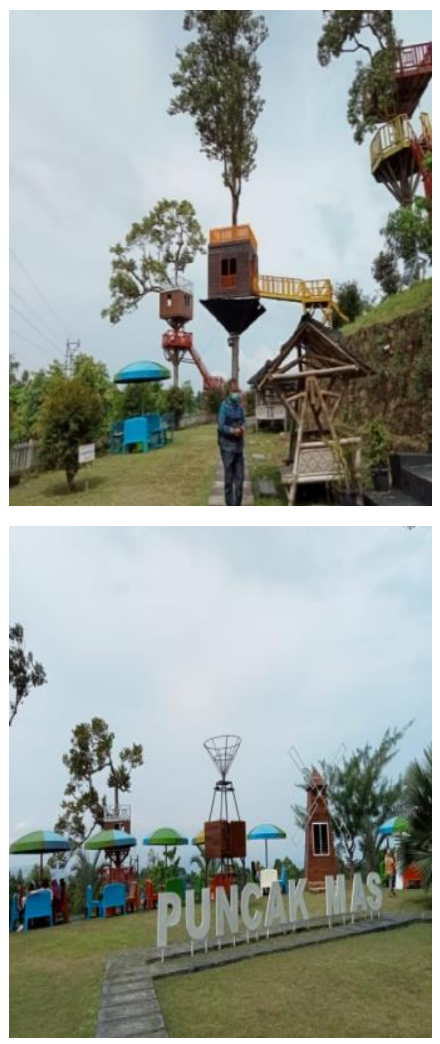

Fig. 7. Puncak Mas mainstay rides

This tourist attraction is also quite safe and has good security rules with the presence of a notice board for the maximum endurance load of several ride objects, such as tree houses and other buildings. In addition, there is also an office and information secretariat for visitors to know about this tourist attraction. However, in terms of tourist security, there are no special officers or special security posts to monitor visitor activities. As a result, it is very susceptible and dangerous because its location is on a steep hill.

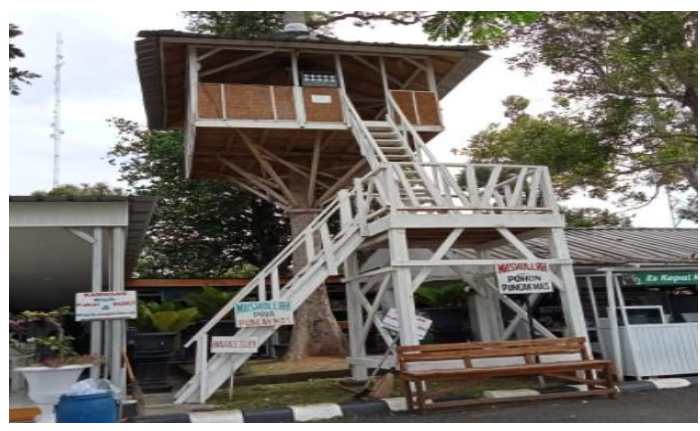

Fig. 8. One of the Facilities for Tourists

Puncak Mas tourist attraction is facilitated with various and complete facilities such as a parking area located under the hill, restrooms, worship places on trees, gazebos at several location points, selfie spots, and children's playgrounds. There is also a food court area or a cafe that serves various kinds of food and drinks to the lodging facility. All these facilities are provided in a clean and beautiful condition. N., \& Haryono, E. (2017). Karst Areas and Prospects for Its Development in Indonesia.

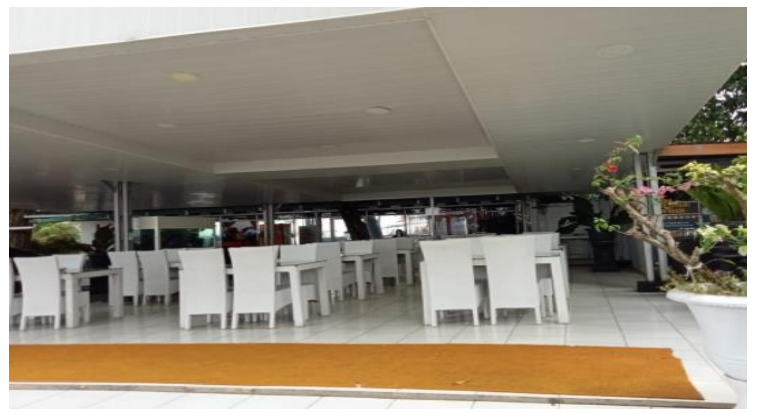

Fig. 9. The Concept of a Luxurious Restaurant and Café

However, in terms of innovation for tourists to have a lasting impression, Puncak Mas has fewer tourist attractions compared to Sakura hill, which has special landmarks, its Japanese culture theme. It can be seen from the minimum number of interesting rides because the focus is only on presenting city views. There are also unexceptional landmarks that characterize the architectural building style in Puncak Mas tourist attraction other than the treehouse. Thus, there are no distinctive and fascinating regional arts and cultural attractions that are unavailable as relying only on live music. 
In terms of food and beverages, this tourist attraction has prepared sufficient facilities for the lower middle class to the upper-class community, but the prices are not yet competitive and adequate to buyers. And lastly, there are no boutiques that sell special souvenirs, especially those that reflect the characteristics of the tourist attraction. In the context of some of the conditions above, this tourist attraction will no longer be attractive for tourists to visit if its sustainability is not well handled in the future. The management needs to think about innovation and improvement to build a good memory for tourists of these attractions.

\section{c) Binoculars Attractions in Bukit Sindy City}

Binoculars Tourism Object Bukit Sindy City is a very strategic tourist attraction, it can be seen from its location in the middle of the city, namely on Jl. Tamin, Pasir Gintung, Tanjung Karang Pusat, Bandar Lampung City. Even though it is in the middle of the city, this location is not easy to access because of the steep and uphill road. And also because the road infrastructure is not yet equipped with safety and security signs. The Sindy hill tourist attraction is the favorite of young people to hang out. However, based on observations in the field, it can be seen that the concept of the Binoculars Tourist attraction in Bukit Sindy City is only as a shop or cafe for young people to hang out. So in comparison with the two tourist attraction concepts, Sakura Hills and Puncak Mas, it can be said that it is still very simple to be called a hill tourist attraction.

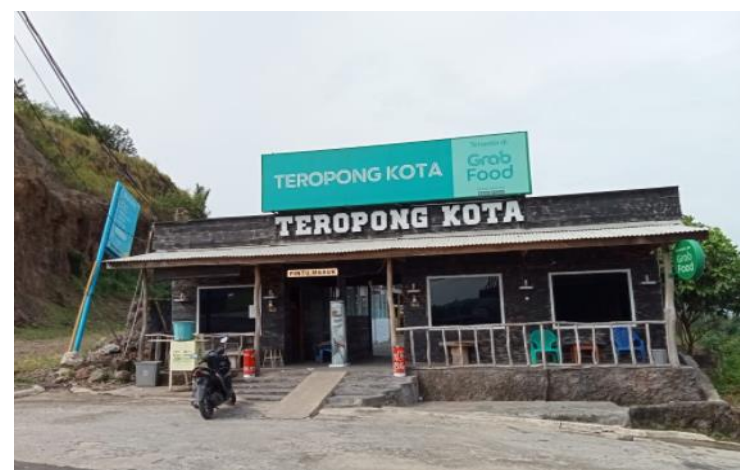

Fig. 10. Café Sindy Hill City Binoculars

The Sindy hill tourist attraction is equipped with facilities in the form of a large parking area for twowheeled and four-wheeled vehicles, a food court that provides a variety of food and drinks, a roofed or openair hangout area with lots of seats, a prayer room, toilets, and various photo spots, as well as performances such as live music on the weekends.

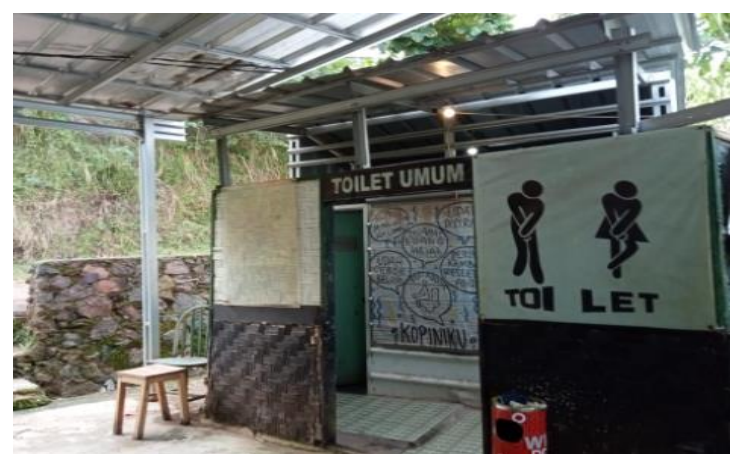

Fig. 11. MCK facilities at the City Binoculars Object

However, various problems arise in the managerial system of these attractions. Start from the building's concept that does not have special landmarks or themes that are not neat and well organized. In addition, based on the observations, the tourist attraction location is unclean because there are a lot of garbage, dirt, and doodles. Furthermore, based on the observations from digital traces of the Sindy Hill tourist attraction, shows that most of the visitors feel uncomfortable and disinclined to go back. This is because of several things, ranging from inappropriate and unclean foods and drinks serving, the food price which tends to be played and expensive, the unfriendly service, even at some spots there are food-stands selling liquor. All in all, the management of the city Binoculars tourist attraction is troublesome and unprofessional, which will threaten this tourist attraction in the future.

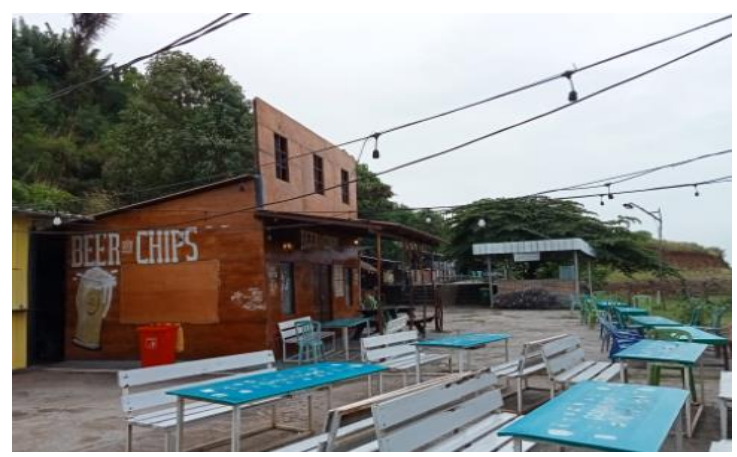

Fig. 12. Young People Hangout

Following the results of the observation above, there needs to be a breakthrough from the Bandar Lampung City government to map the tourism potential and character of each existing hill. And there is a need for commitment and determination to help the development of this hill tourism object, so it continues and maintains a good environmental cycle.

A. Analysis of the use and management of tourism resources based on Sustainable Ecotourism Development

The study on Sustainable Ecotourism Development departs from the concept of Sustainable Development 
Goals (SDGs) where the ideals of state understanding are in designing development that meets aspects of welfare and justice in society as well as environmental resilience. Specifically, development does not only refer to the issue of economic benefits but also needs to pay attention to another important aspect, for instance, aspects of environmental sustainability. This global development agreement document emerged because there were so many inequalities that occurred, especially in the management of natural resources in the Asian region countries. Efforts to pursue economic growth at every level are always driven by the motivation for investment, production, and consumption. This circle of activities contributes greatly to the decline in environmental quality, which in the end will create two problems, namely the shrinking of natural resources and pollution. The practice of growth-oriented development has begun to show a crisis where the potential for forests and biodiversity has been drastically reduced, environmental quality degradation has occurred with massive various disasters, for example, smog, floods, and landslides. Moving on from the various perspectives above, it is necessary to make efforts to straighten the orientation of development by providing justice for a sustainable environment.

To maintain a just environmental ecosystem, the concept of sustainable Ecotourism Development is considered very strategic and important to be given more attention, especially in seeing how economic business practices such as tourism objects do not only look at the issue of benefits but also pay attention to environmental sustainability-based management methods. For this reason, this study uses 4 (four) indicators of achievement from the concept of sustainable ecotourism to the three hill tourism objects in the city of Bandar Lampung, namely, Sakura Hill Tourism, Puncak Mas, and Sindy Hill City Binoculars. The measuring tools are 1 . How a tourist attraction can provide an understanding of the environment's importance as well as creative activities and excellent service. 2. How tourism objects can minimize the negative impacts that can damage the environmental and cultural characteristics of the areas visited. 3 . Involving the community in its management and implementation as well as providing economic benefits. 4. How tourist attractions can continue to survive and be sustainable.

\section{a) Educational and Excellent Nature Tourism}

Based on observations in the field, it shows that the three hill attractions display panoramic views of natural beauty and urban atmosphere as a mainstay spot in bringing tourists. The tourist attractions are located at the top of a hill with a unique, rare, and beautiful landscape that makes it very possible to become a tourist attraction. In addition, the existence of a well- managed tourist attraction on the hill will not only trigger economic growth in the surrounding area but also encourage the sustainability of environmental ecosystems from the increasingly massive environmental degradation that is the city of Bandar Lampung. However, it is interesting that the hill attractions in Bandar Lampung are not all supported in terms of accessibility such as the main road to the tourist attraction. Sakura hill attractions, for example, although the facilities and rides are attractive, the main access to the tourist attraction is very difficult because it is in a narrow location, with damaged roads and minimal signs or notice boards. The case is different in Sindy hill tourist attraction. Even though it is in the middle of an urban area but the road access to the tourist site is very dangerous because of its steep and minimal notices and safety signs. Only the Puncak Mas tourist attraction has good access to tourist locations.

Security and safety issues are also related to the rides operational at the tourist attraction. Based on the field observations, it shows that the rides at the Binocular hill city tourist attraction are unsafe and dangerous for visitors. The supporting infrastructure facilities for the rides are very minimum and it is very dangerous for tourists to visit. It is quite different, compared to building infrastructure at Sakura hills and Puncak Mas, concrete permanent buildings, as well as routine maintenance and safety signs, have been made following visitor safety procedures. However, in the aspect of information services, the three attractions do not yet have a place for a serviced secretariat, only a service information board for visitors. The three attractions also do not have specific guidelines to help tourists recognize aspects of the rides at these attractions. Even, Binoculars and Sindy Hill city have very limited notices or information boards for visitors.

In the aspect of child-friendly tourism, several hill attractions in Bandar Lampung City have prepared spots or rides intended for children, as in Puncak Mas tourism objects. There are seesaws, swings, slides, and so other rides for games. This is very suitable, especially involving children directly that it will give a good influence on children, namely improving children's motor and verbal abilities. Children's playgrounds at tourist attractions can improve children's storytelling skills, especially interest and high curiosity which can then optimize all aspects of their development. The realization of a child-friendly tourist environment is certainly needed so that children can get their right to feel safe and comfortable while in tourist areas. It turns out that not all attractions have rides for children's play, such as the Bukit Mas tourist attraction and the Sindy hill city Binoculars that do not have special rides for children, which will greatly affect the comfort for tourists who will take their children to these attractions. 
In the context of service, the Sakura Hills and Puncak Mas attractions have excellent service, ranging from parking services, consumption, to ride-hailing services for tourists. This service is also supported by several complete public facilities and special facilities ranging from toilets, clean prayer rooms, restaurants and cafe facilities, clean and beautiful gazebo facilities. However, not all facilities are provided for free, such as to enter Puncak Mas area, tourists must buy ticket 2 times because not every ride is free of charge for example some rides at the top of the hill, whereas at Sakura Hill the ticket price is excluded parking fees. On the other hand, the Binoculars Tourist attraction in Bukit Sindy City has not contributed an excellent service, because ticket prices are frequently changing, not to mention the problem of inadequate consumption services and the limited and incomplete facilities.

\section{b) Environmental sustainability and local culture}

If measured in the context of the environmental sustainability of the hills, there is a striking difference between the three attractions. The Sakura hill tourist attraction is still preserving the hill, as seen from the quality of the trees and plants around the tourist attraction. The infrastructure is also made of terraces according to the contours of the hill and is made to have sufficient strength to withstand the load of the building. Therefore the atmosphere of Sakura hill tourist attraction still looks nice and beautiful for visitors to enjoy. This is the same as the Puncak Mas tourist attraction. The infrastructure is very sturdy so that it makes tourists feel comfortable and safe enjoying every ride in the area. The atmosphere of Puncak Mas hill also looks nice because there are still large trees surviving, some even standing as rides or treehouse. However, different things can be seen in the Binoculars tourist attraction of Sindy hill city. The tourist attraction area is on a hill with some of the hills below being eroded by community houses and several spots have been opened for residential areas. Not to mention that Sindy Hill looks steep and lacks shade trees so it looks like a bald hill. If it is left unchecked, it will be very dangerous for the people under the hill because it can cause landslides at any time, including tourists who visit the Binoculars Tourist attraction in Bukit Sindy City.

In addition to the issue of environmental sustainability, local wisdom is one of the important characteristics to be used as a tourist attraction. The local wisdom can be in the form of customs or culture that exists in people's lives and is feasible to be applied in tourist attractions. Tourists who visit will be interested in the local culture and they have the opportunity to learn the culture of the area, vice versa. The culture brought by tourists from their homes can affect the socio-cultural life of the community as the process of assimilation and interaction between cultures will occur. Therefore, in tourism development activities, one must be able to uphold the regional identity which is the hallmark and value of local wisdom. If they collide with the three natural attractions, then the three attractions will not be able to take advantage of the potential of Lampung local wisdom such as the customs and culture of the Lampung people. The Sakura Hill tourist attraction introduces Japanese culture in various rides. As for Puncak Mas, it doesn't have any rides related to local wisdom, as well as with the Binoculars Attractions in Sindy Hill City.

\section{B. Collaboration with local communities}

Community development based on nature tourism can include the role and participation of the surrounding community. Therefore, the efforts and programs rolls out in developing tourism objects must be able to encourage community members to participate sustainably, so that the potential owned by an area and the community can be optimally developed. By utilizing, extracting the potential of nature and society sustainably, the development of hill tourism objects will have an impact on improving the surrounding community welfare. Efforts to achieve this aim require the involvement of various related parties, in this case, are the government, developers, and the community itself. In addition to this, synergistic coaching between tourism actors must be done continuously. Coordination and communication between interested parties are needed so that the development of tourism objects will meet the shared expectations and goals.

If it clashes with the facts on the ground showing the tourist attraction of Sakura Hill, Puncak Mas and Sindy Hill City Binoculars both open up space for business people to participate in opening their business in the area for a fee. On the other hand, several tourist objects such as Sakura Hill and Puncak Mas also provide opportunities for selected local communities to become employees of these attractions sites. Some people are allowed to open business access to tourist attraction entrances. However, based on the observations, it is not seen that local MSME products are traded at the tourist attraction mentioned above. The absence of these MSME products certainly makes the attraction sites less attractive, therefore in the effort to develop the tourism object area in the future, it is necessary to pay attention to MSME products.

\section{Innovation and Creativity of Tourist Attractions}

The implementation of nature tourism activities must support the efforts to preserve the environment and culture to improve the welfare of the community. To achieve this goal, there needs to be careful planning for the management of tourism objects based on innovation and creativity. In the context of potential attractions, the three attractions have a special theme as a unique one, namely natural panoramas. The beauty of 
natural scenery and urban areas is the main supporting attraction for tourist objects, apart from relying on natural panoramas. Only Sakura Hill attractions have secondary supporting attractions, namely the uniqueness of Japan and the attributes in it. This secondary attraction is not available in the other two attractions neither the Puncak Mas tourist attraction nor the Sindy Hill City Binoculars tourist attraction. With the existence of a special theme on Sakura Hill tourist attraction, tourist activities will also increase, not only to enjoy nature but also to enjoy the treats of various Japanese cultural-themed activities such as Japanese costumes, selfie spots at Japanese homes, and shop for Japanese cultural ornaments. Even the existing rides are integrated and packaged attractively. However, the three attractions have not been able to package the main and supporting attractions as an education, though educational tourism can give more benefits.

\section{CONCLUSION}

The three attractions have natural attractions by paying attention to aspects of environmental sustainability. But in the service aspect, only 2 (two) tourist objects are managed professionally, namely the Sakura Hills and Puncak Mas attractions, while the Sindy Hill City Binoculars tourism object does not yet have a sufficient managerial system because the services and access to the facilities are limited. Moreover, the local culture aspect has not become a priority to be used as a special theme for the tourism object. Otherwise, in the aspect of community involvement, the three tourism objects have opened access to the surrounding community to participate in managing and sharing economic benefits. Serious attention of tourism actors to develop innovation and creativity-based tourism is needed, especially in the Binocular tourist attraction in Bukit Sindy City.

\section{REFERENCES}

[1] Anggraeni, A. A, Analysis of the economic impact of marine tourism on people's income on Tidung Island. Loka Design, 1(1), 2013.

[2] Suwantoro, G, In his book Fundamentals of Tourism. Yogyakarta: Publisher Andi, 2004.

[3] Siregar, R, Human resources in national development. Pros. Semin. Nas. Tah. Fac. Social Science. Univ. Meda Country, (1), 378-381, 2017.

[4] Setijawan, A, Sustainable tourism development in socioeconomic perspective. Journal of Planoearth, 3(1), 280735, 2018.

[5] Regional Regulation No. 6 of 2012 concerning the Master Plan for Regional Tourism Development of Lampung Province.

[6] Lampung Province Regional Regulation Number 1 of 2010 concerning Regional Spatial Planning (RTRW) of Lampung Province from 2009 to 2029.

[7] Bandar Lampung City Regulation Number 10 of 2011 concerning Regional Spatial Planning (RTRW) of Bandar Lampung City 2011-2030.

[8] Bandar Lampung City Regulation Number 03 of 2017 concerning Tourism. 